\title{
Lessons Learned from a Decade of Sudden Oak Death in California: Evaluating Local Management
}

\author{
Janice Alexander - Christopher A. Lee
}

Received: 30 October 2009/ Accepted: 21 May 2010/Published online: 18 June 2010

(C) The Author(s) 2010. This article is published with open access at Springerlink.com

\begin{abstract}
Sudden Oak Death has been impacting California's coastal forests for more than a decade. In that time, and in the absence of a centrally organized and coordinated set of mandatory management actions for this disease in California's wildlands and open spaces, many local communities have initiated their own management programs. We present five case studies to explore how local-level management has attempted to control this disease. From these case studies, we glean three lessons: connections count, scale matters, and building capacity is crucial. These lessons may help management, research, and education planning for future pest and disease outbreaks.
\end{abstract}

Keywords Local management .

Participatory management - Capacity building .

Forest health - Forest pest management .

Non-native/invasive species · Sudden Oak Death

\section{Introduction}

Landscape managers of urban and wildland forests have long understood that eradication of a new pest is practicable only in the early stages of a given outbreak, before the pest population builds to an uncontrollable or

\footnotetext{
J. Alexander

Cooperative Extension, University of California,

Novato, CA, USA

e-mail: jalexander@ucdavis.edu

C. A. Lee $(\bowtie)$

Cooperative Extension, University of California, 5630 South Broadway, Eureka, CA 95503, USA

e-mail: cale@ucdavis.edu
}

widespread level (Council for Agricultural Science and Technology 2003; Waring and O'Hara 2005). It is especially hard to attempt plant disease control when the disease has a latent or incubation period that allows the causal pathogen to become well-established before it is detectable (Gilligan 2008), as in the case of Sudden Oak Death in California and Oregon. What management options, then, are available when the point of eradication opportunity is well past? As forest health educators, we work with land managers, homeowners, and policy-makers to address this issue as it relates to Phytophthora ramorum, the cause of Sudden Oak Death. For an actively spreading epidemic disease like Sudden Oak Death, in which eradication is impracticable in some areas but might still be effective in others, it may be helpful to review management actions throughout the range of the disease to highlight the effective disease work that is occurring, recognize its limitations, and provide context for the applicability of these approaches as a model for working with future pest outbreaks.

Sudden Oak Death first appeared in California in the mid 1990s, but reaction to the disease reached a fever pitch in 2000 when large numbers of oaks were seen dying in coastal counties from no known cause. We now know that Sudden Oak Death is caused by an exotic microorganism, $P$. ramorum, which genetic evidence strongly suggests came into California on the leaves of imported nursery plants (Ivors and others 2006; Mascheretti and others 2008). In North America, this pathogen is currently found in the forests of 14 California counties, in the forests of one county in Oregon, and on plant stock within the nursery trade. For the purposes of this discussion, we will focus only on the forest infestations in California, where Sudden Oak Death is found in forests and wildlands managed by a wide variety of public and private entities and is generally well established. 
Initially, the cause of the oak tree deaths in California was unknown, and there were fears that the mysterious epidemic might spread to more trees or throughout the rest of the state. These concerns prompted quick local action and a call for additional assistance at higher government levels. Nationally, the USDA Forest Service has administered almost $\$ 30$ million in $P$. ramorum research funding and in education and management grants since the beginning of the epidemic (Government Accountability Office 2006; K. Britton, USDA Forest Service, personal communication, June 2008). Within California, the California Department of Forestry and Fire Protection oversaw an initial \$3.8 million in state funding in 2002, but California has not provided funding to address this disease since then (California Oak Mortality Task Force 2008). Additionally, the non-profit California Oak Mortality Task Force (COMTF; described below) works within California and assists nationally to coordinate education and management recommendations for P. ramorum and Sudden Oak Death.

Sudden Oak Death has severely impacted plant communities on public (e.g., Los Padres National Forest, Point Reyes National Seashore, Muir Woods National Monument, several state and county parks), quasi-public (e.g., San Francisco Public Utilities Commission, Marin Municipal Water District, Mid-Peninsula Regional Open Space District, Kashia Reservation), and private lands. The disease's wide and patchy distribution has proven problematic for management and control decisions. By the time the causal pathogen was identified and named, it was too wellestablished in and around the greater San Francisco Bay area to warrant the kinds of eradication attempts that have since been made in Oregon, where land managers can still enumerate and treat individual infected trees each year (Goheen and others 2004; Kanaskie and others 2006; Hansen and others 2008). Rigorously-applied silvicultural measures, similar to the Oregon eradication regime, could potentially slow disease spread at the fringes of the California infestation; however, the state and federal regulatory agencies with jurisdiction over private California forestlands have declined to attempt such efforts. These agencies have refrained from following Oregon's lead because they interpret the scope of their responsibilities to pertain only to commercial forestry activities, non-forestry agriculture, activities directly affecting wildlife, or activities directly affecting water quality, with no agency claiming lead responsibility for overall forestland protection. Thus, continued spread is likely, especially in Mendocino, Humboldt, and Del Norte Counties, where plant community types and precipitation regimes are favorable to pathogen establishment (Meentemeyer and others 2004, 2008).

Scientifically-tested recommendations for managing forests impacted by $P$. ramorum are still in development, although at least three promising directions have emerged: application of systemic fungicides (Garbelotto and Schmidt 2009), forest thinning to remove susceptible hosts (Valachovic and others 2008), and targeted removal of the main carrier, California bay laurel, near coast live oak trees (Swiecki and Bernhardt 2008). However, uncertainty about effective management actions remains.

Into this absence of definitive management direction have stepped a variety of concerned groups working at many scales, from individual neighborhoods to county government staff to regional and statewide collaborations. Some of these groups are socially based neighborhood communities in the familiar sense, while others are more formally defined professional organizations of practitioners, groups of politicians, or tribes; some are longstanding and others ad hoc. While the overarching infrastructure provided by federal funds and agencies has been crucial to the support of these organizations' activities and to the scientific development of experimental treatments, the motivation and focus on action has come from this ground level. The value of the following case studies lies in their illustration of such groups' effectiveness at serving their wider communities during new pest outbreaks by bridging this gap between centrally-directed control actions and the development of scientifically proven management interventions for individual landowners.

\section{Theoretical Context and Methodology}

These case studies did not emerge from an objective methodology. Rather, they represent nine years of personal experience with the development of Sudden Oak Death in California. This paper seeks to review and learn from shared, observed experience rather than to test predetermined hypotheses against collected data-although there is ample need and scope for the latter. Our perspective is twofold: we have provided individual and community-level assistance and education related to Sudden Oak Death throughout its range in California, and we have participated in designing and implementing experiments to help develop recommendations for practical treatment of the disease at a variety of scales. Working within these roles has given us a more comprehensive, synoptic understanding of the management, research, and education activities related to Sudden Oak Death than is available to most individual researchers or managers or larger, more distant government agencies. This bottom-up approach to information-sharing and management recommendation was recently and explicitly recommended in an opinion by Smith and others (2009).

We further augmented personal observations with media reports and discussions with colleagues. Then we compiled a number of case studies of how specific groups addressed 
their own particular Sudden Oak Death issues, and we submitted these case studies for factual review by the players themselves and by the scientists who have studied $P$. ramorum in California since its discovery. In this way, our narratives represent the collective observations of a scientific and educational community working to understand and manage this emerging forest disease. We ultimately combined different story lines to create five case studies that highlight consistent, local-level management approaches to Sudden Oak Death within California (see Fig. 1).

Our analysis of the case studies below does not try to determine the "right" or "wrong" treatment strategy for forests impacted by Sudden Oak Death in California. Instead, we share how these cases comment on the literature of local action in the face of threats to the natural environment.

The case studies examine this action in the instance of Sudden Oak Death, comparing the local responses we have observed at many scales against some common social theories of community involvement, and comparing management of this particular forest pest against other threats to wildland systems. From this comparison, we extract

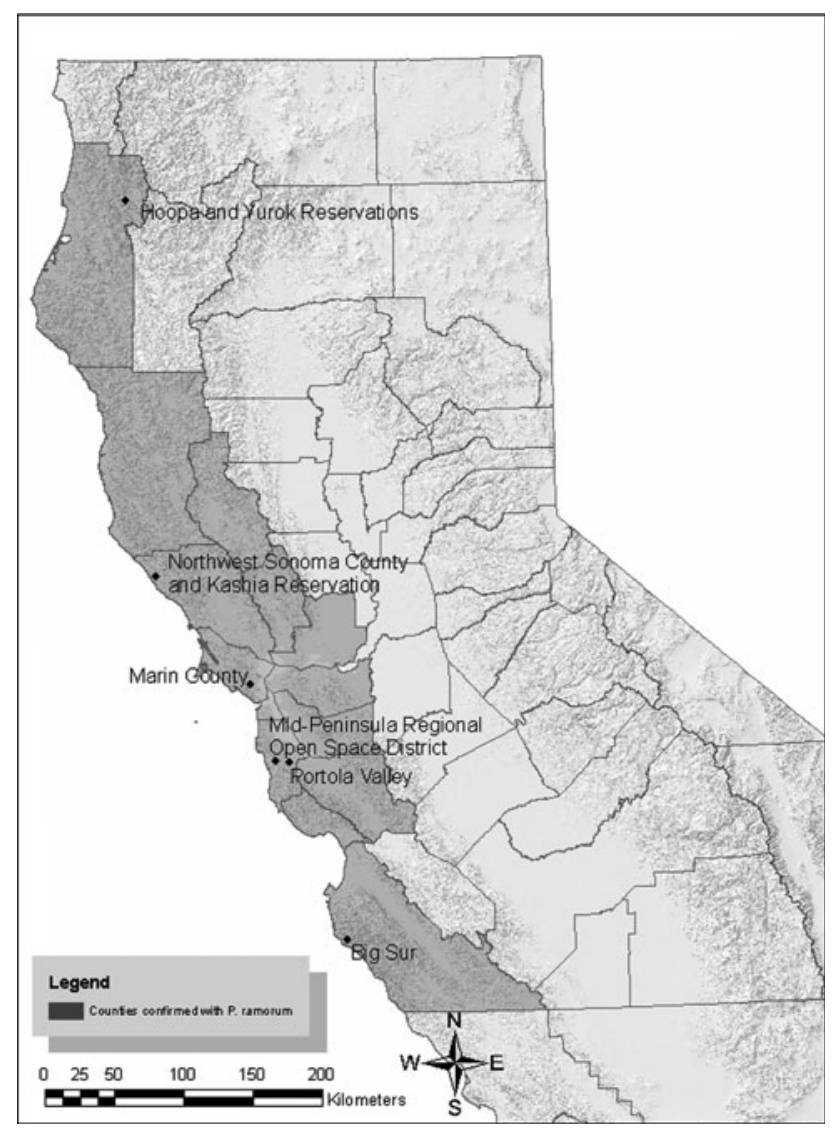

Fig. 1 Locations of California communities referred to in case studies three lessons that suggest that local management responses to epidemic outbreaks of forest pathogens and insect pests may be structured at a deep level by a variety of characteristics shared by local groups. We also suggest that if these characteristics are taken into account and worked with, the apparent "randomness" of local-level management can be incorporated into more concerted, larger-scale efforts as well as into attempts to more accurately model the spread of a pest or pathogen.

Social scientists have extensively analyzed the conditions underlying local organization and action, including that related to the natural environment. Tilly (1973) proposed socioeconomic and sociopolitical criteria that are necessary for such action, including the following: sufficient economic resources within the local group to gain attention to the problem of concern; a focus on close, common physical surroundings rather than wide geographic dispersal of group members; and the perception that the group does not yet have a voice in the management of the problem. Michaels and others (2006) suggested that "focusing events," defined as sudden events that have the potential to cause harm, are often necessary to catalyze group formation and action. Flint and Luloff (2007), focusing specifically on forest pest outbreaks, theorize that communities are most likely to act to preserve the forest environment from large-scale disturbance when the community perceives itself to be greatly at risk from such disturbance and when it has sufficient internal "interactional capacity," or sufficiently organized and developed social relationships, to respond adequately. On the basis of survey data, Flint and Luloff (2007) also conclude, counterintuitively, that communities respond more readily to broad-based ecological threats than to immediate threats.

In some ways, the threat of invasive organism spread into communities resembles the threat of wildland fire. Fire scientists and fire management professionals have invested increasing amounts of time and energy in recent years to understand how local dynamics can facilitate or impede the implementation of fuels treatments and other firewise actions in the wildland-urban interface (e.g., Brunson and Schindler 2004; Carroll and others 2004, 2006; Cheng and Becker 2005; Brooks and others 2006; Edwards and others 2008). This research often highlights the diversity of communities with different ways of solving problems (Cheng and Becker 2005; Brooks and others 2006) and recommends that fire management professionals adopt a similar diversity of community-generated definitions of "success" rather than expecting a unified result across all communities (Brooks and others 2006). When wildfires give rise to community conflict, this is often because extralocal authorities respond to emergencies by trying to impose an efficient solution that is resisted by locals whose practices are embedded in social or spiritual values rather 
than rational and technocratic ones (Carroll and others 2006). These findings are supported by other writing about natural resources management that in general favorably reviews public, participatory management over private, technocratic management and decentralized management over centralized management (Gale and Miller 1985; Moote and McClaran 1997; Lane 1998; Mascarenhas and Scarce 2004; Keough and Blahna 2005; Lejano and others 2007; Rist and others 2007; Higgins and Duane 2008).

This enhanced understanding of the diversity of community values and the sources of community resistance to some forms of management has led to a strong recent focus on collaborative learning and citizen science. The growing trend of citizen science, or using volunteers to collect data, conduct monitoring, and perform repetitive scientific support tasks, has been reviewed positively for its power to efficiently contribute to pure science (Cohn 2008; Delaney and others 2008; Howard and Davis 2009; Sullivan 2009). In terms of a more applied science such as wildland fire management, Cheng and Becker (2005) emphasize that collaborative learning fosters the productive relationships between communities and professional natural resource managers that are necessary for sustained community fire protection over the long term. Shared learning within the community — not just between the community and outside professionals-is important too. One prerequisite of successful community-based management is that the community members reach a "shared cognition" about the goals of management, so that everyone is on the same page (Gass and others 2009). Pretty (2003) finds community management a promising solution to the problem of managing the commons, although he points out that community organization can have a dark side if the community's shared cognition sanctions harm to natural resources.

\section{“Local” Response}

Much of the foregoing literature uses the term "community" for a variety of social and spatial groupings existing for a wide variety of purposes. The concept's malleability has subjected its use to criticism by Kumar (2005) and Flint and others (2008), for example, who contend that the word is too vague as a reliable guide for analysis unless it is explicitly theorized for the particular analysis. We have tried to stick to using the word "local" for the scale of action we are describing in the case studies here. We recognize that "local" is potentially vulnerable to some of the same criticisms as "community." However, unlike "community," the use of "local" carries no pretense of precision, instead being generally understood by what it is not (in our intended sense, that which is not "global," "federal," or "state"). It is precisely the flexibility of scale implied by this word that we are trying to highlight in these case studies.

The case studies presented below range over the gamut of possible senses of "local." At one end of the spectrum, we include a consortium of concerned citizens, policymakers, and scientists (the California Oak Mortality Task Force) that, in its size and in the existence of coordinating staff, resembles an NGO to some extent. At the other end, we include true local communities in the sense commended by Flint and others (2008): groups of people motivated by concern for a common place, for common resources, for common management goals, or for common ideals. In between, we include some actors with governmental roles, including individual tribes and county governments. What unites these disparate groups under the rubric of the "local" is that they stand apart from the two groups that have traditionally played the main roles in public pest and disease management: (1) large-scale federal or state government agencies and (2) academic scientists housed in institutions with national or statewide reach. These are the groups who typically impose the efficient, technocratic environmental management solutions of which Carroll and others (2006) write. Although some of the local groups in our case studies may contain individual representatives from each of these larger levels, there are important differences between the two levels. The groups highlighted here are smaller in scale, more ad hoc, and more informal; they are not individuals; and they have coalesced around common interests.

Unlike state and federal government agencies, county/ tribal governments and individual agency employees lack the capacity for unilaterally imposing the region-wide insect and disease management efforts that may be necessary for complete eradication or control. Unlike academic scientists per se, many of the groups we discuss are motivated by attachment to a specific place or region. Unlike most NGOs, the COMTF does not implement actions; instead, it creates the preconditions for effective action by assembling information and coordinating the dissemination of scientific knowledge. We call all of these groups "local" for lack of a better word to characterize the proactive nature of their actions absent a similar proactive response from better-resourced state and local governments.

\section{"Effective" Response}

Local responses to forest insect and disease threats are necessarily limited in scale (Gass and others 2009) and rarely extensive enough across the landscape to adequately respond to an epidemic (Holdenrieder and others 2004; Gilligan 2008). However, rather than viewing these efforts through the lens of biological insufficiency, it is possible to view them in the positive light of community capacity 
development and of citizen science. Thus, "effective" disease management can have more than one meaning. Most of the local management efforts detailed in these case studies are not effective in the sense of eradicating $P$. ramorum or slowing its spread on a large scale. However, they are effective in the sense of alleviating pathogen impacts on a smaller scale; in stimulating local involvement with natural resource management; in enhancing group capacities for useful citizen science by providing testing-grounds for new management techniques; and in preparing for more effective pest outbreak responses in the future.

Many formal and informal retrospective analyses of community responses to disease and insect outbreaks have been performed. Some of these (e.g., Cannon and Worley 1980; Anagnostakis 1997; Gottwald and others 2002) concentrate on economic or biological factors relative to treatment effectiveness, while others (e.g., Parkins and McKendrick 2007; Flint and others 2008) focus on community vulnerability, resilience, capacity development, and sociopolitical responses to large-scale forest disturbance. The following case studies and analysis contribute to this literature in two ways: first, by the lessons we can draw to inform future responses, and second, by highlighting the role that this local management plays as a necessary adjunct to scientific investigation of disease management.

\section{Case Studies: Local-Level Disease Management in California}

Case Study: Local Initiative Leads to Statewide Leadership and Coordination

Beginning in the mid 1990s, the University of California Cooperative Extension (UCCE) in Marin County received a barrage of calls and requests for help from homeowners with dying oak trees. Large numbers of dead trees were also prompting concern among local fire officials. As the problem intensified across the county, it was clear that some action was required, even though the cause of the tree mortality was still unknown. A Marin County Supervisor, Cynthia Murray, took the lead and tasked a key group of county departments with creating a working group to address the issue. Then, in January 2000, the Marin County Board of Supervisors officially supported the formation of a local Marin County Oak Mortality Task Force. The first Marin task force meeting took place soon after with over 75 attendees, including representatives from public agencies, elected officials, landscape professionals, and several interested UC researchers.

Especially in the beginning of the Sudden Oak Death epidemic, funding was needed to support the huge public demand for information and technical assistance. UCCE Marin and Marin County Supervisor Murray worked to obtain $\$ 15,000$ from the local county government and an additional $\$ 20,000$ from a local foundation to fund outreach efforts. They also launched a publicity campaign to alert the press and gain attention to their cause. This allowed for the dissemination of information beyond just the locally affected neighborhoods in the county to other parts of the state beginning to experience a similar situation.

Then, shortly after the cause of Sudden Oak Death was confirmed in the summer of 2000, the California Department of Forestry and Fire Protection (CDF) and the California Forest Pest Council formed the California Oak Mortality Task Force (COMTF). The timing was more than coincidental. Over the course of several previous months, the two different groups had been exchanging phone calls and coordinating their next actions. Though the groups agreed to join forces and focus specifically on Sudden Oak Death, tensions and uncertainty as to the causal agent of the disease led them to compromise on the more general phrase of "Oak Mortality" in the Task Force name rather than highlighting any specific cause.

In November of that same year, Marin County Supervisor Cynthia Murray convened the first Sudden Oak Death Summit to bring together a wider range of concerned citizens and policymakers from every level of government. Sixty lobbyists, legislators and local decision makers from the then six affected counties (Marin, Sonoma, Napa, Santa Cruz, San Mateo, and Monterey) attended. At that session, Governor Gray Davis announced \$100,000 for the Oak Mortality Task Force and Under Secretary of Agriculture Jim Lyons showed federal commitment via an $\$ 800,000$ pledge and a request for $\$ 2.4$ million in additional federal funds for Sudden Oak Death.

This recognition and funding bolstered the goal of moving Sudden Oak Death from a local cause to an issue of state and national importance. As a subcommittee of the non-profit Pest Council, the COMTF could not lobby for funding but could provide technical assistance and advice. One of the most important tasks COMTF members initially were called upon to do was to compile a document to inform legislators of prioritized research, policy, education and management needs. Indeed, in 2001, four state legislators proposed Sudden Oak Death bills to address the issue in California.

It soon became clear that forests were not the only impacted systems when the first U.S. nursery was found infested in December 2000 (California Oak Mortality Task Force 2008). From the beginning, the COMTF played a large role in providing information to support the creation of regulations and quarantines to contain $P$. ramorum, and the role of the nurseries in potentially spreading the 
pathogen made these actions all the more important. Having provided assistance to state regulators initially, COMTF was then able to assist federal regulators in quickly reacting to infestations in national, wholesale nurseries a few years later.

The policy recommendations supplied by the COMTF are deemed especially valuable because they come from a consensus-driven process. The COMTF has grown to encompass over 80 agencies and more than 1,000 members and actively seeks to include input from public agencies, non-profit organizations, and private interests. Lead researchers act as Science Advisors so that the COMTF has access to the latest scientific findings and can quickly translate them to management recommendations. All of these efforts help ensure that policymakers, land managers, and homeowners have access to the latest science, and that it is vetted by a diverse group of experts before bearing any stamp of approval. This multi-agency, coordinated approach has been highlighted as a model for response to future outbreaks (National Association of State Foresters 2004). While the COMTF has no regulatory authority or management mandates, it provides a vital role in bringing together smaller players at various agencies and throughout different regions of the state. In this way, both the early Marin task force and the larger California body act to focus and expand the interests and efforts of local individuals.

\section{Case Study: Activism and Management at the County Level}

Disease levels in Sonoma County remained relatively low through the first 5 years of the Sudden Oak Death epidemic in California. However, in 2006, tree mortality exploded in the forests in western Sonoma County, especially around the Russian River corridor. Homeowners were not able to keep up with the increasing number of dead tanoaks needing removal in the forests surrounding their homes and looked to the County and other government agencies for assistance. A COMTF-sponsored public meeting in Guerneville in 2006 turned confrontational as landowners demanded to know why nothing was being done about the piles of dead tanoaks in the steep, forested canyons where they lived.

Energized individuals began an aggressive letter-writing campaign to neighbors, newspapers, and elected officials, demanding action be taken. In response, Sonoma County agencies convened local, state and federal officials to appeal for assistance in addressing the concerns of affected homeowners. The USDA Forest Service provided funds to the Sonoma County Department of Emergency Services and UCCE Sonoma County offices to respond. With a grant of approximately $\$ 150,000$, two temporary staff positions were funded to write a strategic response plan for the
County and to conduct public outreach on the issue. A Technical Advisory Group was also convened to advise and coordinate management efforts.

Twenty-two community meetings were held throughout the county in 2007 , directly reaching over 870 people. The Sonoma County Sudden Oak Death Strategic Response Plan, presented to the Sonoma County Board of Supervisors in January 2008, addressed the following issues: current and potential $P$. ramorum infection throughout the county; risks and effects of the disease; the impacts of tree mortality on fire behavior; and current and future requirements of local and state agencies to deal with spread and mortality issues (Bell and others 2008). In response, the Board gave Sudden Oak Death and fire management a higher budgetary priority within the County budget and continued to seek avenues of funding for dealing with issues pertaining to Sudden Oak Death.

In the meantime, with assistance from the coordinating staff, Fire Safe Sonoma, a non-profit fire prevention organization, obtained grant funding for two projects specific to helping homeowners deal with tree mortality related to P. ramorum. First, with a grant from Pacific Gas \& Electric Co. that was augmented with labor donated by Davey Tree Service, Fire Safe Sonoma launched a chipper program for neighborhoods impacted by Sudden Oak Death. This partnership between homeowners and tree care companies provides some financial assistance to homeowners in order for them to reduce the fuel volume near their homes, thereby also reducing fire risk for the surrounding area.

Additionally, the Bureau of Land Management funded Fire Safe Sonoma to implement the Sonoma County Sudden Oak Death Fuels Mitigation and Defensible Space Project. This project will aid homeowners who are faced with the expensive challenge of creating the required 100 feet of home-surrounding Defensible Space in areas where Sudden Oak Death has killed many trees. The project is in the early implementation stages, and is anticipated to be successful (C. Safford, Sonoma County Department of Emergency Services, personal communication, June 2009). However, demand from homeowners requesting help continues to outstrip funding available to help them.

\section{Case Study: Monitoring for Early-Stage Disease} on Large Forested Landscapes

The Hoopa and Yurok Reservations in northern Humboldt County contain large areas of tanoak, and these tribes expressed great concern about the possibility that $P$. ramorum could decimate culturally important stands of trees on their reservations. The affected tanoak trees not only are key traditional food sources for the tribe but are also viewed as sacred trees; other culturally important plants are also hosts for the pathogen. While the pathogen 
has not yet been recovered from that area of Humboldt County, the forest infestation only fifty miles away in the southern part of the county makes the threat of infection great. In cooperation with UCCE and the UC Davis Rizzo Lab, the Hoopa and Yurok reservations agreed to participate in a watercourse monitoring network aimed at early detection of $P$. ramorum in streams, the first places that the pathogen is detectable in watersheds. Because of their intense concern for preserving both specific tanoak groves and the culturally important tanoak resource in general, tribal forestry managers saw watercourse monitoring as a way to get the earliest possible signal that trees may be infected with $P$. ramorum, enabling them to implement any road closures, stepped-up educational programs, or host removal measures as quickly as possible.

The Hoopa and Yurok reservations worked with UCCE and UC Davis to pinpoint the largest and most frequently visited streams in the reservations and receive training on how to conduct the monitoring programs themselves. Once forestry staff were trained in the stream baiting procedures, they began to implement the monitoring with their own people. Although the pathogen has not yet been recovered from reservation land, tribal forestry managers and UC staff are confident that, along with the rest of their extensive watercourse monitoring network in place throughout northwest California, should the pathogen reach the reservations, observers will detect it at an early stage, giving them the widest number of options for proactive disease management.

\section{Case Study: Cooperative Strategies Among Small Landowners}

The traditional gathering grounds and 40-acre reservation of the Kashia Band of Pomo Indians are in the heart of $P$. ramorum-infested forests in western Sonoma County. Once it was clear that Sudden Oak Death was impacting their lands, the tribe's main concerns were to (1) limit further spread of the pathogen on gathered plants; (2) manage hazard trees near buildings on the reservation; and (3) attempt to protect uninfected tanoak on the reservation. After the USDA Forest Service and COMTF first spoke with Kashia tribal members and staff in fall 2003, in 2005 the State and Private Forestry division of the Forest Service agreed to provide approximately $\$ 20,000$ to the Kashia for managing Sudden Oak Death on their lands. The tribe then contracted with private and university researchers to study a preventative treatment; tribal staff and researchers worked closely with neighboring properties to lay out plots and monitor the research. The treatments included spraying susceptible tanoak trees with a phosphonate compound (Garbelotto and Schmidt 2009), while sanitation efforts included education about symptoms on commonly collected plants and steps to disinfect shoes and equipment. Additionally, over the course of six years, the Kashia were able to improve safety on the Rancheria by removing approximately 25 hazard trees.

Also in 2005, a gardening group from Portola Valley (a small, forested community along the peninsula south of San Francisco) requested a presentation from the COMTF to explain the increased mortality they were seeing close to their homes. The garden meeting audience was at capacity and included a staff member from the Town of Portola Valley, who then took the information and sense of urgency back to the town administration. Over the course of the next year, there were an additional nine Sudden Oak Death community meetings and workshops throughout San Mateo and adjoining Santa Clara County. After each small town-hall style presentation, homeowners and local leaders began working together to address the issues facing their communities.

Farther south, in the steep, fire-prone canyons of Big Sur, homeowners worked with their local Fire Safe Council, volunteer Fire Brigades, and county and state agencies to remove dead trees from the defensible space around structures. This coordinated effort resulted not only in funding (through fundraising and grants) but also in regulatory allowances to ease the permitting process for tree removals. And across the greater San Francisco Bay Area, Homeowners Associations facilitated cooperation amongst individual homeowners to receive preventative treatments in bulk from tree care professionals. Many additional communities also participated in research initiatives to better map and thus manage the disease on a smaller, community scale through the "Sudden Oak Death Blitz" program led by Matteo Garbelotto of UC Berkeley.

In each of these cases, different landowners and interest groups came together to treat and manage large areas of private land at once, which not only provided financial savings to individual homeowners but also benefitted the overall community by protecting forest growing across multiple ownerships. There was no guarantee that all affected homeowners would participate, and to be sure, there was not $100 \%$ participation in these community efforts. However, for the individuals who did participate, they did gain a financial advantage by partnering with their neighbors, which likely allowed for more land to be protected than if each homeowner worked alone. This group participation also moved action toward a positive momentum where neighbors were encouraged to work together rather than opting out of the work because it only affected their property or bottom line.

Though these community efforts often occur on a neighborhood-by-neighborhood level, the cumulative effect across the scale of the entire state is greater. 
Additionally, one of the more important, and perhaps unintended, consequences of tribal involvement with Sudden Oak Death is the personal connection that tribes have brought to tanoak mortality. While some western foresters, landowners, and land managers minimize the threat of Sudden Oak Death by pointing out that forests are generally overstocked with tanoak, the Kashia and others speak passionately about the importance of tanoaks to the forests and their way of life. The high degree of access that neighbors gave the Kashia to conduct their experiments is a testament to this positive effect.

Case Study: Adaptive Management on Mid-Sized Public Lands

In 2003, the Mid-Peninsula Regional Open Space District (MROSD) was looking for guidance on best management practices (BMPs) to keep P. ramorum from spreading from already infested preserves to uninfested areas under its management. While the San Francisco Bay Area counties the District occupies (San Mateo and Santa Clara) were regulated zones for the pathogen, no restrictions were in place inside the regulated area to limit the spread of the pathogen on a more local level. Since the District was considering asking their public visitors to take sanitation measures to reduce pathogen spread, resource management personnel felt it was important for the staff and crews to also be consistent with this request when it came to sanitation and BMPs.

Phytophthora ramorum had first been confirmed on MROSD lands in October 2000. Although there had been informal discussions about preventing the spread of $P$. ramorum, nothing had been formally written, and there was a lot of uncertainty about which practices were the most effective. After reviewing other BMPs created for general audiences, MROSD realized that it needed to create its own set of best practices that could be more easily understood by its staff and were generally consistent with its standard work practices. Given the many uncertainties surrounding Sudden Oak Death and the lack of hard science to support many of the proposed sanitation measures, however, staff understandably expressed some resistance and skepticism to taking unproven actions which would interfere with usual work practices.

Nonetheless, MROSD felt it needed to be a leader in reducing the local spread of the pathogen within and among its preserves. Taking the best available science at the time, resource managers focused on the activities that seemed to have the greatest spread risk and crafted management responses intended not only to slow pathogen spread but also to meet other District goals. Measures included cleaning equipment, such as trucks, chainsaws, and boots, between infested and non-infested parcels. After the program began, field crews agreed that the BMPs were worthwhile and not as difficult to implement as they had feared. One staff member even commented that chainsaws were working better because Sudden Oak Death requirements that they be cleaned more often resulted in their also being lubricated more often. MROSD also found that the reach of the $P$. ramorum BMPs extended beyond Sudden Oak Death: the sanitation measures implemented also related to invasive weed seeds and other general land management issues.

In addition to their willingness to proactively implement management activities in the absence of complete certainty as to their effectiveness, MROSD has also played an important role by leveraging resources. Simply put, their active involvement allowed additional funding and resources to flow into research on managing $P$. ramorum in wildlands. Other nearby land management agencies, such as the San Francisco Public Utilities Commission, have since joined this large-scale "experiment" in managing wildlands and have brought their own staff and funding to the table. Even private landowners who are dealing with parcels in the tens of acres are willing to jump in with land, time, and money to try these untested management techniques in an effort to both save their local trees and contribute to the larger understanding of successful wildland management of the pathogen.

The experience of these management "pioneers" highlights a common management problem of needing to act before scientific consensus has been reached. Their situation is typical in California, where infestations in already heavily infested counties are not targeted for action. For the MROSD, it made a huge local difference whether one parcel was infected while a neighboring one was not, but the coarser county-level view of the state and federal agencies did not support this. This work also shows the importance of building BMPs and treatment strategies from the ground up and not trying to force a one-size-fits-all solution onto smaller, more local issues.

\section{Discussion}

The case studies above draw on at least ten different management actions being taken against $P$. ramorum across California. As mentioned earlier, the biological effectiveness of these actions is equivocal, but they serve a strong social purpose. The strength of these actions lies in their close connection to actual problems and communities on the ground; the weakness lies in their reliance on specific communities' commitment to initiate and continue these actions. From the case studies, we have extracted three common lessons concerning local response to Sudden Oak Death that help explain when and how a group pulled 
together to take some sort of action. These lessons may help predict how certain communities might react to the environmental threats of the future.

\section{Lesson \#1: Connections Count}

The experience of the Marin County community, which quickly used its resources to muster an explosion of publicity about Sudden Oak Death that attracted attention and more resources, illustrates how a focusing event (Michaels and others 2006) can catalyze the initiation of locallydriven environmental management. However, the conditions of this initiation, and of the local group's ability to sustain its efforts, depend upon a variety of factors. Marshall and Jones (2005) note that wealthy and educated people are most likely to participate in community natural resources management activities. Affluent, urbanized neighborhoods discretely concentrated in space, such as in Portola Valley, are more likely to have the social network, time, money, and energy to get together to attempt integrated disease management than relatively poorer neighborhoods in, say, rural Sonoma County, where housing and networks alike are widely dispersed. As another example, one of the few integrated management plans to emerge in California was written by the Santa Lucia Conservancy, which manages large tracts of open space interspersed with large private properties near the wealthy community of Carmel. The development of this management plan was made possible largely through the volunteered time and energy of community landowners (C. McCormick, Santa Lucia Conservancy, personal communication, February 2009).

Moreover, the success of affluent communities like Marin County at attracting funds and attention to a perceived environmental problem suggests that success is not only a matter of interested citizens bringing their personal money to the table. Even more important is that these citizens have the connections and the understanding of civic processes (for example, the phone numbers of county supervisors or how to deal with a city council agenda) needed to attract the attention of the politicians, government agencies, and nongovernmental organizations that can access financial resources in adequate amounts. The relative absence of this political know-how does not prevent management from happening; it just slows down the management timeline. In the case of local groups like those in Sonoma County, where the perception of an environmental risk developed more slowly, by the time citizens did become motivated to attract those organizations and agencies they were willing to band together to more effectively leverage available funds, such as the BLM fuels reduction money, or to donate in-kind labor or money to help deal with disease impacts.
Lesson \#2: Scale Matters

Our case studies and other informal observations suggest some differences between groups working to manage Sudden Oak Death at the urban forest scale and those working to manage it at a larger wildland scale. The urban forest scale appears more spatially contained than the wildland scale; properties in the urbanized setting are more accessible and generally easier to work on; and the visual landscape of the urban forest is less dense, promoting collective monitoring of disease status. The scale of California wildlands, on the other hand, can appear overwhelming. Many private property owners in California probably refrain from active management of their forestlands simply because they feel lost in a sea of vegetation (see Megalos (2000) for documentation of this in North Carolina). In non-urban forests, residents living far from governmental centers either rely on their own knowledge (Wear and Greis 2002) or receive help from organized nongovernmental organizations such as watershed restoration organizations, tribal organizations, fire safe councils, or extension agencies; this support is often suggested by the organization rather than actively sought by the communities themselves. The more urbanized the invaded forest, the more likely property owners are to be "squeaky wheels," rather than relying on a go-it-alone, independent management ethic.

This difference in scale and perception between urban and rural forests helps explain some of the difference in timing between the Marin County and Sonoma County responses to Sudden Oak Death. Although the two counties share a border and a reputation for urbane "Bay Area" lifestyles, large portions of Sonoma County are located in the heavily forested, very rugged Coast Range. In these remote rural areas, which are heavily impacted by SOD, forest management issues are complex and multi-faceted. Access and topographic constraints may limit awareness of forest health issues for all but the most active landowners, and these constraints certainly limit the available palette of practical management tools. In Marin County, where people could see the disease in their backyards and neighborhood parks, a clear perception of a broad ecological problem emerged early. Observant hikers and landowners noticed the rapid death of trees along trails and in the urbanized green space, motivating relatively swift communication of the problem and expressions of concern from active citizens. This supports the ideas of Flint and Luloff (2007) about the value of this broad-based, ecological community concern. However, in Sonoma County, where residents are farther-flung and the living experience more rural, concern did not mount to the same degree until the accumulating mortality near homesites presented a clear and present fire risk. 
This suggests that community risk perception will vary depending on the nature, structure, and scale of the community's forested environment. Rapid observation, risk perception, and action in Marin County hinged on the pathogen's invasion of structured urban forests with spatial elements that lend themselves to public participation and observation, such as hiking trails, widely-spaced oak woodlands, and neighborhood parks. In Sonoma County, the pathogen was more likely to be found in dense Douglas-fir/hardwood and redwood forests, in areas with steep canyons, small private roads, limited access, and large stretches of continuous vegetation. Even the public parks in Sonoma County where the pathogen was found in the late 1990s are very large and relatively sparsely developed (e.g., Annadel State Park, Armstrong Redwoods State Natural Reserve, Austin Creek State Recreation Area, Jack London State Historic Park).

This difference in scale also explains why the efforts of the Hoopa and Yurok tribes to apply the most effective early detection protocols across their large and rugged landholdings are crucial to their hopes of preventing largescale $P$. ramorum invasion on their reservations. These techniques can help the tribes' land management staffwhose technical training gives them an advantage over neighborhood groups - to make up for the difficulties that dense forests and difficult topography put in the way of detecting a microscopic pathogen.

\section{Lesson \#3: Building Capacity is Crucial}

The groups who successfully implement local management actions have in common an increased knowledge base and better interactional capacity among themselves. Building these competencies for other communities, or enhancing them where they already exist, seem a way to empower communities to take even more active roles in local management of Sudden Oak Death and other pests of the future.

Because of the importance of a community's perception of its risk, clear and non-technical explanations add great value to the more technical risk assessments usually produced for new pest outbreaks. Interpreters of technical information can play a crucial role in enlisting public support for forest pest management efforts (Moser and others 2009). In the case of Sudden Oak Death, the COMTF plays a role in strengthening community-driven efforts by supplying such non-technical interpretations of relevant scientific findings through the development of educational materials and by making a public information officer available for press releases and educational events. As the Sonoma County example shows, it may be difficult for communities to appreciate $P$. ramorum as a broadbased ecological threat to the forest as a whole. Because the pathogen often produces inconspicuous and even cryptic symptoms, communities generally become aware of the problem only after it has escalated, making management extremely expensive and more difficult. Typically, many people living within the distribution of Sudden Oak Death are indignant about what they perceive as a lack of effort by the scientific and land management community to educate the public about the disease, despite the publicity and extensive educational efforts it has inspired to date. This makes the formulation of ever more innovative and proactive outreach strategies imperative.

Additionally, the difficulty of perceiving Sudden Oak Death as a broad threat is exacerbated by the low-value status of the primary host to sustain lethal infections, tanoak. Owing to past management activities, coastal California forests typically feature large numbers of small tanoak trees that suffer from a variety of native disease and insect pests which can help mask the initial symptoms of a P. ramorum invasion (Baumgartner and Rizzo 2001; J. Marshall, California Department of Forestry and Fire Protection, personal communication, August 2006). Additionally, and more importantly, tanoak trees have little market value and compete with conifers for water and sunlight, making them problematic in forests managed for conifer timber. In such an atmosphere, it can be difficult to convince skeptical audiences of tanoak's innate value, its support of wildlife, its cultural value to Native tribes, or the possibility that its disappearance from forests could cause ecological harm in indirect ways. Even in Marin County, concern sharply rose when coast live oaks, rather than tanoaks, were seen to be infected by the disease. This situation places groups attempting to mobilize to combat the disease at a disadvantage. Historically, disease suppression efforts have attracted the most funding and governmental support when they involve commercially important or visually dominant tree species (Cannon and Worley 1980; Anagnostakis 1997; Brasier and Buck 2001; Gottwald and others 2002; Kinloch 2003; Schmidt 2003). It is possible that if commercially valuable species such as redwood or Douglas-fir had been threatened in a substantial way by the pathogen, management early on would have moved beyond the community-based level discussed in this paper. Seen in this light, COMTF, as a group advocating for the preservation of the tanoak resource, has little influence relative to groups fighting diseases that affect more valuable plants. This is why it has been effective for COMTF to bring speakers from the Kashia Reservation to training events and conferences to relate tanoak's importance to their culture. Developing interactional capacity between local groups is as important as developing it within them. In the case of the Hoopa and Yurok tribes, the threat of Sudden Oak Death has inspired the tribes to seek out cutting-edge scientific techniques for pathogen detection. Taken together with the Kashia's effectiveness at educating the public 
about the importance of tanoak, these tribal examples demonstrate how a two-way flow of information into and out of communities can enhance overall disease management efforts in a region or state.

Existing literature and the variety of experiences outlined in these case studies suggest that biological emergencies such as wildfire or other disturbances have the potential not only to test community bonds, but also to strengthen them and develop increased community capacity for dealing with environmental threats. In the case of Sudden Oak Death, this has proven to be true at a larger organizational scale: in response to a recent wave of oak mortality in southern California caused by other pests, both public officials and private individuals referenced existing resources and lines of communication originally created to deal with Sudden Oak Death (Susan Frankel, USDA Forest Service, personal communication, June 2009).

For communities already invaded by $P$. ramorum, the management task has become dealing with disease impacts (hazard tree removal, fuels reduction) and determining effective techniques for long-term disease management on a smaller scale. As scientists sought to begin developing such techniques, the communities identified in these case studies began to step up with in-kind contributions: properties to use as outdoor laboratories, staff and volunteer time, intra-community educational efforts, and some funds of their own. On quasi-public lands (e.g., Mid-Peninsula Open Space District, Kashia Reservation, San Francisco Public Utilities Commission), generalist natural resource managers decided to take constructive action against the problem even in the absence of scientifically tested solutions. By developing collaborative relationships with $P$. ramorum specialists, scientists, and educators, these communities enlarged their capacities for action while participating in a very applied brand of citizen science.

\section{Conclusion}

The decentralized management shown in the case studies above has obvious potential to enhance community selfempowerment. Centralized management, in both the forms of imposed quarantines or trade restrictions and eradication activities undertaken, risks sparking local conflict of the kinds that Carroll and others (2006) mention. Some of this local distrust of centralized management has manifested itself in the case of Sudden Oak Death, when local groups have expressed their fear that the costs of management are more onerous than the consequences of leaving a forest disease unmanaged. For example, in the case of P. ramorum management in Humboldt County, one local land manager, while generally supporting Sudden Oak Death management activities involving removal of tanoak and bay laurel trees, confided that he feared a "destroy the village to save it" outcome. Community-based management gives each community the power to determine its own cutoff points.

However, in an inversion of this, another kind of conflict exists when a community would like to take strong action but then realizes that it cannot influence the larger socioeconomic or biological factors that may be responsible for the plant pathogen's entry into the environment or its persistence there. $P$. ramorum's presence in California wildlands and neighborhoods depends partly on human activities such as the global trade in ornamental plants. Disease spread could also potentially be mediated by landscaping or arboricultural activities, recreation, and movement of wood, soil, or other plant materials from area to area. Many of these activities are important to regional and national economies, and reconfiguring them to discourage plant pathogen movement (for example, by changing protocols for trade in plants and plant propagation) is a task that goes well beyond the local scale in length and complexity of negotiation and the number of participants required to effect change. Even if regulations are changed, enforcement may be impossible in a practical sense, as in the case of firewood movement for commercial sale inside California. Additionally, funding for disease management efforts fluctuates with the fortunes of regional economies and governmental budgets, and forest health tends to get less funding and attention compared to the health of agricultural commodities. In this situation, the community's adroitness at engaging the political system is again important.

This second kind of conflict is the one that has manifested itself most often in the course of Sudden Oak Death management in California, as local groups have generally clamored for more guidance, help, and regulation rather than less. Of course, had every group received all the management help it wanted, it may be that many of them would feel differently and the first kind of conflict would reassert itself. For example, in Brookings, Oregon, where strong centralized disease management has been imposed, a few local groups have at times expressed displeasure with some of the consequences of that management (Weissman 2007).

Ultimately, local management can at most extend to only a part of the landscape (Gass and others 2009). When one local group's decision to not act will affect other groups, who should be empowered to serve as arbiter? The overlapping interdependencies between individuals or groups when it comes to pest issues can in many ways resemble the issues around water and air quality. This telescopes up even to the scale of federal government management. For example, how is it possible to maximize the forest protection mission of the USDA Forest Service 
by limiting new pest introductions while simultaneously working with importers of non-native plants and animals through the USDA Animal and Plant Health Inspection Service? Effectively answering these vexed questions would probably require revision, re-prioritization, and re-writing of rules at a massive governmental level, to include input from affected and interested parties across the country on a variety of natural resources-related topics such as trade in plants and forest products, watershed and wildlife protection, local economies, and many others. These heady questions are beyond the scope of an article like this, but national, collaborative groups such as the Continental Dialogue on Non-Native Forest Insects \& Diseases may provide a model for addressing these paradoxes in the future. Simply writing an "Invasive Species Act" (something that people working in pest management sometimes call for) might not adequately accommodate competing priorities, but might rather add another layer of competing bureaucracy to already existing protective and proscriptive laws. The depressing truth is that such an effort, to be done properly, would require a level of political will and sustained attention likely to be present only in a prolonged period of economic prosperity-or of obvious environmental emergency.

The case studies in this paper may be instructive for the management of pest outbreaks in the future. While each pest outbreak will follow a somewhat unique narrative based on a number of factors, if we move beyond just an understanding of the biological and ecological factors at play to also consider the societal constraints, we may better be able to manage and control the impacts of that event. From the example of Sudden Oak Death, we can see the large role that community characteristics can play in determining which, if any, local management action may be taken. We suggest that the three lessons outlined above could potentially be incorporated into landscape-level disease and pest control planning in the future. Similarly, they could potentially be incorporated into efforts to provide informative models of the landscape-level spread of disease-causing pathogens and pests, especially those models that take the effects of various management activities into account.

The former instance (incorporating these lessons into landscape-level planning) would involve gathering sociological, demographic, and political data about affected communities at the beginning of a disease or pest outbreak, at the same stage that other basic data about the disease or pest are being gathered. Information about monetary resources available to affected landowners or land managers could be integrated with information about the structure and spatial scale of affected forests in the "neighborhood" and subjective characterizations of important community values to obtain indices of vulnerability (as in Parkins and
McKendrick 2007), interactional capacity (as in Flint and Luloff 2007), and other indicators that might guide interested outside facilitators, managers, and coordinators where best to focus their efforts at helping those communities face the environmental threat. This points to a need for research into and development of such indices, especially ones that could be developed from rapidly administered surveys or interviews of citizens in affected areas.

Similarly, these three lessons could conceivably aid in the development of more accurate models of pathogen or pest spread across the landscape. Recent efforts to model the spread of Sudden Oak Death have combined an ecological niche-based approach, which predicts the likelihood of pathogen persistence in the landscape based on its host and climatic requirements, with a dispersal capability approach, which takes account of the pathogen's dispersal methods and dispersal limitations (Meentemeyer and others 2008). Additionally, scientists are working on incorporating the effects of various management decisions into these models to provide land managers with realistic disease management scenarios that will enable them to compare the virtual consequences of various management decisions with each other (J Filipe and C Gilligan, University of Cambridge; R. Meentemeyer, University of North Carolina-Charlotte; and D. Rizzo, University of California-Davis, personal communication, February 2010). Incorporating the same sociological and demographic information described above into these models could enhance prediction by providing at least crude estimates of the likelihood of widescale versus small-scale management action, the likely swiftness of management action, or the likelihood of resistance to such action, in a given area.

Along with these considerations, citizen science and educational capacities need to be nurtured in order to build more effective disease management efforts earlier in affected communities, as Moser and others (2009) emphasize. The non-professional and community coordination that has been stimulated by $P$. ramorum will undoubtedly enable a better response to the next forest pest to appear in California. When community capacity to manage the natural environment is actively fostered, communities can jump-start the process of dealing with new pests while facilitating the scientific search for proven control technologies. The value of this dynamic demonstrates that community coordination and education are worthy of sustained effort and ongoing cultivation and are more than simply reactive adjuncts to research and management activities during new pest outbreaks.

Acknowledgments Thank you to the many reviewers, anonymous and known, who greatly assisted in tightening the focus of this paper and improving it from start to finish, especially Susan Frankel, 
Deborah Chavez, and Stephanie Pincetl. Thank you to the USDA Forest Service, Region 5 State and Private Forestry, for funding.

Open Access This article is distributed under the terms of the Creative Commons Attribution Noncommercial License which permits any noncommercial use, distribution, and reproduction in any medium, provided the original author(s) and source are credited.

\section{References}

Anagnostakis SL (1997) Chestnut blight: the classical problem of an introduced pathogen. Mycologia 79(1):23-37

Baumgartner K, Rizzo D (2001) Distribution of Armillaria species in California. Mycologia 93(5):821-830

Bell L, Safford C, Vossen P, Rosevear J, Perry C (2008) Sonoma County sudden oak death strategic response plan: University of California Cooperative Extension and Sonoma County Department of Emergency Services. Available from Sonoma County Department of Emergency Services, Santa Rosa, CA

Brasier CM, Buck KW (2001) Rapid evolutionary changes in a globally invading fungal pathogen (Dutch elm disease). Biological Invasions 3:223-233

Brooks JJ, Brenkert H, Serby JE, Champ JG, Simons T, Williams DR (2006) Integrating social science into forestry in the wildland/ urban interface. Fire Management Today 66(2):35-43

Brunson MW, Schindler BA (2004) Geographic variation in social acceptability of wildland fuels management in the western United States. Society and Natural Resources 17:661-678

California Oak Mortality Task Force (2008). USA Phytophthora ramorum nursery chronology. Accessed online August 16, 2009: http://www.suddenoakdeath.org/html/chronology.html

Cannon WN Jr, Worley DP (1980) Dutch elm disease: performance and costs. Res. Pap NE-457. U.S. Department of Agriculture, Forest Service, Northeastern Forest Experiment Station, Broomall, PA

Carroll MS, Cohn PJ, Blatner KA (2004) Private and tribal forest landowners and fire risk: a two-county case study in Washington State. Canadian Journal of Forest Research 34:2148-2158

Carroll MS, Higgins LL, Cohn PJ, Burchfield J (2006) Community wildfire events as a source of conflict. Rural Sociology 71(2):261-280

Cheng AS, Becker DR (2005) Public perspectives on the "wildfire problem". Fire Management Today 65(3):12-15

Cohn JP (2008) Citizen science: can volunteers do real research? BioScience 58(3):192-197

Council for Agricultural Science, Technology (2003) Integrated pest management: current and future strategies. Council for Agricultural Science and Technology, Ames, IA, p 246

Delaney DG, Sperling CD, Adams CS, Leung B (2008) Marine invasive species: validation of citizen science and implications for national monitoring networks. Biological Invasions 10:117-128

Edwards GP, Allan GE, Brock C, Duguid A, Gabrys K, VaarzonMorel P (2008) Fire and its management in central Australia. The Rangeland Journal 30:109-121

Flint CG, Luloff AE (2007) Community activeness in response to forest disturbance in Alaska. Society and Natural Resources 20:431-450

Flint CG, Luloff AE, Finley JC (2008) Where is "community" in community-based forestry? Society and Natural Resources 21(6):526-537

Gale RP, Miller ML (1985) Professional and public natural resource management arenas: forests and marine fisheries. Environment and Behavior 17(6):651-678
Garbelotto M, Schmidt DJ (2009) Phosphonate controls sudden oak death pathogen for up to 2 years. California Agriculture 63(1):10-17

Gass RJ, Rickenbach M, Schulte LA, Zeuli L (2009) Cross-boundary coordination on forested landscapes: investigating alternatives for implementation. Environmental Management 43:107-117

Gilligan CA (2008) Sustainable agriculture and plant diseases: an epidemiological perspective. Philosophical Transactions of the Royal Society 363:741-759

Goheen E, Hansen E, Kanaskie A, McWilliams M, Osterbauer N, Sutton W, Rehms L (2004) An eradication strategy for Phytophthora ramorum in Oregon forests. Phytopathology 94:S35

Gottwald TR, Graham JH, Schubert TS (2002) Citrus canker: the pathogen and its impact. Plant Health Progress. http://www. apsnet.org/online/feature/citruscanker/. Accessed 26 Oct 26, 2009

Government Accountability Office (2006) Invasive forest pests: lessons learned from three recent infestations may aid in managing future efforts. Government Accountability Office, Washington, DC, $118 \mathrm{pp}$

Hansen EM, Kanaskie A, Prospero S, McWilliams M, Goheen EM, Osterbauer N, Reeser P, Sutton W (2008) Epidemiology of $P$. ramorum in Oregon tanoak forests. Canadian Journal of Forest Research 38:1133-1143

Higgins TL, Duane TP (2008) Incorporating complex adaptive systems theory into strategic planning: the Sierra Nevada Conservancy. Journal of Environmental Planning and Management 51(1): 141-162

Holdenrieder O, Pautasso M, Weisberg PJ, Lonsdale D (2004) Tree diseases and landscape processes: the challenge of landscape pathology. Trends in Ecology and Evolution 19(8):446-452

Howard E, Davis AK (2009) The fall migration flyways of monarch butterflies in eastern North America revealed by citizen scientists. Journal of Insect Conservation 13:279-286

Ivors K, Garbelotto M, Vries IDE, Ruyter-Spira C, Hekkert BT, Rosenzweig N, Bonants P (2006) Microsatellite markers identify three lineages of Phytophthora ramorum in U.S. nurseries, yet single lineages in U.S. forest and European nursery populations. Molecular Ecology 15:1493-1505

Kanaskie A, Goheen E, Osterbauer N, McWilliams M, Hansen E, Sutton W (2006) Eradication of Phytophthora ramorum in Oregon forests-status after 6 years. In Proceedings of the Sudden Oak Death third science symposium. General technical report. PSW-GTR-214. U.S. Department of Agriculture, Forest Service, Pacific Southwest Research Station, Albany, CA

Keough HJ, Blahna DJ (2005) Achieving integrative, collaborative ecosystem management. Conservation Biology 20(5):1373-1382

Kinloch BB Jr (2003) White pine blister rust in North America: past and prognosis. Phytopathology 93:1044-1047

Kumar C (2005) Revisiting 'community' in community-based natural resource management. Community Development Journal 40(3):275-285

Lane MB (1998) Affirming new directions in planning theory: comanagement of protected areas. Society and Natural Resources 14:657-671

Lejano RP, Ingram HM, Whiteley JM, Torres D, Agduma SJ (2007) The importance of context: integrating resource conservation with local institutions. Society and Natural Resources 20(2):177-185

Marshall BK, Jones RE (2005) Citizen participation in natural resource management: does representativeness matter? Sociological Spectrum 25:715-737

Mascarenhas M, Scarce R (2004) "The intention was good": legitimacy, consensus-based decision making, and the case of forest planning in British Columbia, Canada. Society and Natural Resources 17:17-38 
Mascheretti S, Croucher PJP, Vettraino A, Prospero S, Garbelotto M (2008) Reconstruction of the sudden oak death epidemic in California through microsatellite analysis of the pathogen Phytophthora ramorum. Molecular Ecology 17:2755-2768

Meentemeyer R, Rizzo D, Mark W, Lotz E (2004) Mapping the risk of establishment and spread of Sudden Oak Death in California. Forest Ecology and Management 200:195-214

Meentemeyer RK, Anacker B, Mark W, Rizzo DM (2008) Early detection of emerging forest disease using dispersal estimation and ecological niche modeling. Ecological Applications 18: 377-390

Megalos MA (2000) North Carolina landowner responsiveness to forestry incentives. PhD. dissertation, North Carolina State University, Raleigh, NC, 119 pp

Michaels S, Goucher NP, McCarthy D (2006) Policy windows, policy change, and organizational learning: watersheds in the evolution of watershed management. Environmental Management 38: 983-992

Moote MA, McClaran MP (1997) Implications of participatory democracy for public land planning. Journal of Range Management 50(5):473-481

Moser WK, Barnard EL, Billings RF, Crocker SJ, Dix ME, Gray AN, Ice GG, Kim M-S, Reid R, Rodman SU, McWilliams WH (2009) Impacts of nonnative invasive species on US forests and recommendations for policy and management. Journal of Forestry 107(6):320-327

National Association of State Foresters (2004) Preparing for invasive species outbreaks: a workbook for state foresters. http://www.state foresters.org/node/791. Accessed 26 Oct 2009

Parkins JR, MacKendrick NA (2007) Assessing community vulnerability: a study of the mountain pine beetle outbreak in British Columbia, Canada. Global Environmental Change 17:460-471

Pretty J (2003) Social capital and the collective management of resources. Science 302:1912-1914
Rist S, Chidambaranathan R, Escobar C, Wiesmann U, Zimmermann A (2007) Moving from sustainable management to sustainable governance of natural resources: the role of social learning processes in rural India, Bolivia, and Mali. Journal of Rural Studies 23:23-37

Schmidt R (2003) Fusiform rust of southern pines: a major success for forest disease management. Phytopathology 93(8):1048-1051

Smith RJ, Verissimo D, Leader-Williams N, Cowling RM, Knight AT (2009) Let the locals lead. Nature 462:280-281

Sullivan R (2009) Citizen science breaks new ground. ECOS 149: $10-13$

Swiecki TJ, Bernhardt EA (2008) Increasing distance from California bay laurel reduces the risk and severity of Phytophthora ramorum canker in coast live oak. In Proceedings of the Sudden Oak Death Third Science Symposium. General technical report. PSW-GTR-214. U.S. Department of Agriculture, Forest Service, Pacific Southwest Research Station, Albany, CA

Tilly C (1973) Do communities act? Sociological Inquiry 43(3-4): 209-240

Valachovic Y, Lee C, Marshall J, Scanlon H (2008) Wildland management of Phytophthora ramorum in northern California forests. In Proceedings of the Sudden Oak Death science symposium, Santa Rosa, CA, pp 305-312

Waring KM, O'Hara KL (2005) Silvicultural strategies in ecosystems affected by introduced pests. Forest Ecology and Management 209:27-41

Wear DN, Greis JG (eds) (2002) Southern forest resource assessment. Gen. Tech. Rep. SRS-53. U.S. Department of Agriculture, Forest Service, Southern Research Station, Asheville, NC, 635 pp

Weissman L (2007) Azalea Park tree removal: residents have questions, city and state have answers. Curry Coastal Pilot. November 3, 2007. Western Communications, Inc, Brooking, OR 